International Journal of Business Management and Economic Review

Vol. 2, No. 03; 2019

ISSN: 2581-4664

\title{
IMPACT OF BELT AND ROAD AND REVERSED GLOBALIZATION TO MALAYSIA- CHINA ECONOMIC RELATIONSHIP
}

\author{
Wai Mun HAR ${ }^{a *}$, Sin Yee LEE ${ }^{a}$, Chong Heng LIM $^{\mathrm{b}}$, Ai Lian TAN ${ }^{\mathrm{b}}$ \& Chai Thing TAN \\ ${ }^{a}$ Faculty of Accountancy and Management, Universiti Tunku Abdul Rahman, Malaysia. \\ ${ }^{b}$ Faculty of Business and Finance, Universiti Tunku Abdul Rahman, Malaysia.
}

\author{
http://doi.org/10.35409/IJBMER.2019.0117
}

\begin{abstract}
International trade and foreign direct investment are growth catalyst for developing countries like Malaysia. Among common determinants of trade and foreign investment, infrastructure and international relation surprisingly get lesser attention. Institutionalization of Belt and Road Initiative (BRI) could give new attention and importance to Malaysia-China international relation, especially in economic aspect. Reversed globalization trend among developed Western world and changing federal government in Malaysia further added attraction and debate issues to Malaysia-China partnership under BRI. In Malaysia context, doubt remains on whether BRI are compatible with ASEAN Economic Community (AEC) and capable to bring mutual benefits to both China and Malaysia under contemporary scenario. Thus, this paper aims to discuss three related questions. Firstly, is there a "reversed globalization" trend now? Secondly, is BRI compatible with AEC? Thirdly, will BRI mutually benefit China and Malaysia? This paper demonstrates signs of reversed globalization in major Western countries; BRI plays an important and significant role in enhancing ASEAN economic partnership; and Malaysia-China partnership through BRI does potentially brings mutual benefit in term of namely filling up Western deglobalization void, making Malaysia as ASEAN-China Gateway, and trade enhancement..
\end{abstract}

Keyword: Belt and Road Initiative (BRI), ASEAN Economic Community (AEC), Reversed globalization Malaysia, China, Trade, Foreign Direct Investments (FDI).

\section{INTRODUCTION}

After the World War II, globalization waves gathered pace. Fall of Soviet Union and Berlin Wall paved ways for greater global capitalism where multinational corporations established around the world. International trades increased from US\$4.88 billion in 1970 to US\$44.58 billion in 2015 (World Bank database), which is more than $800 \%$ in about 45 years. Malaysia total trade also increasing from RM14.37 billion in 1970 to RM452.70 billion in 2015 (Figure 1), which is a remarkable $3050 \%$ or 30 times! Increment in trade accelerated after 1990, implying the impact of globalization and continuously advancement in logistic sector. However, two events shocked the world. They are Brexit and Donald Trump's United States Presidential election victory. On $23^{\text {rd }}$ June 2016 referendum, "leave European Union" won with a simple majority of $51.9 \%$. Possible 


\section{International Journal of Business Management and Economic Review}

Vol. 2, No. 03; 2019

reasons are "take control" sentiment and immigrant issue (New York Times 2016). In United States, Donald Trump's promised to protect and make America "Great Again" with antiglobalization measures. Trump's immediate actions include cancelled Trans-Pacific Partnership Agreement (TPPA), restricted immigrants and threated of tax punitive to get United States' offshore investment back home. Some take Brexit and Trump's victory as sentiment of reversed globalization. How will it impacts on Belt and Road Initiative (BRI) as well as China and Malaysia's economic relationship becomes an interesting research scope.

Figure 1a: Trade trend for World and Malaysia $(1970$ - 2015)



(Data source: World Bank databank; value in real term 2010 based year)

There are four main issues to focus. Firstly, is there a reversed globalization wave (issue \#1)? It is important to determine the direction of current globalization trend because the role and potential impact of BRI may be different. BRI under globalization trend may face fewer obstacles but will it make big impact? If whole world is de-globalizing, BRI may have difficulties gaining worldwide support and ended up only as bilateral trade with China for few participating countries. Secondly, how can BRI position itself to link the world economies into its trade routes (issue \#2)? BRI has to be different and stand out from other international trade initiative like TPPA and be compatible with Asian Economic Communities (AEC). Third and fourth, what benefits can BRI bring to China (issue \#3) and Malaysia (issue \#4) respectively? Belt and Road has to be relevant especially to Malaysian economy in current trends. On Malaysia aspect, concern will be focused on the compatibility of BRI to our long term economic plan and Asian Economic Communities (AEC) challenges. These four issues form the research framework as illustrated in Figure 1b.

\section{Figure 1b: Research Framework}


International Journal of Business Management and Economic Review

Vol. 2, No. 03; 2019

ISSN: 2581-4664

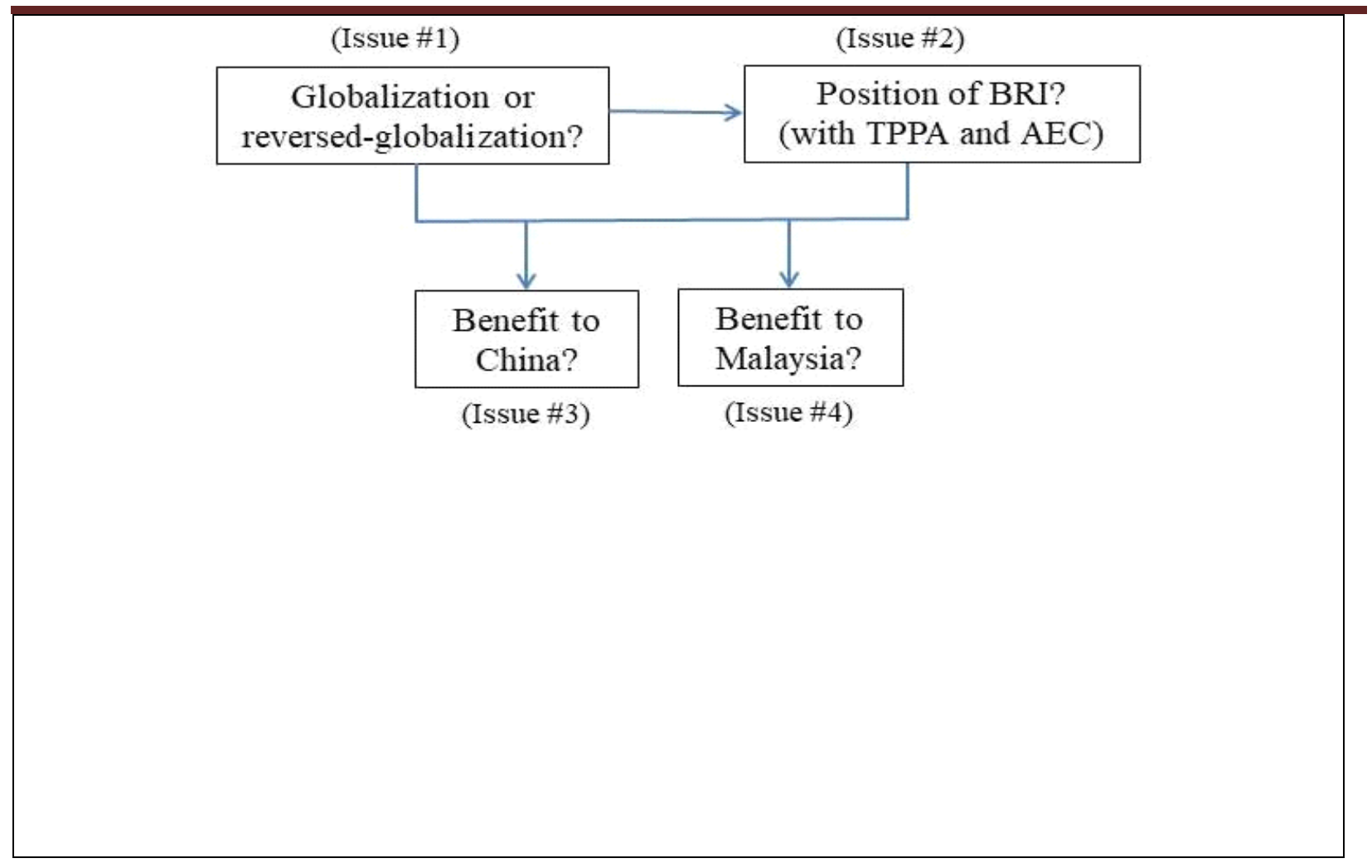

Issue \#1: Reversed globalization?

Some look at Brexit and Donald Trump's victory as isolated shocks only. In a recent research interview, Dr. Shivee Ranjanee, senior lecturer in Universiti Pertanian Malaysia (UPM) who published a lot in international trade area, argued those events happened to two countries only, namely United Kingdom and United States. In contrast, ASEAN countries are increasing their effort for regionalization like Asian Economic Communities (AEC) and Regional Comprehensive Economic Partnership (RCEP) especially after United States pulled out of TPPA. China is aggressively promoting their global economic integration in "One Belt, One Road" (also known as "Belt and Road") initiatives. On the other perspective, KOF Economic Globalization Index (Dreher 2006) shows different trends of globalization for developed Western countries (Figure $2 \&$ Figure 3). All selected European countries, United States, Canada and Australia have reversed economic globalization trend since 2000 while Australia, Indonesia and Philippines (Figure 4) turn downwards off their peak in later years. Most developing countries of Asia (including Malaysia) show rapid economic globalization advancement (Figure 4). Globalization Index trended steadily flat to slightly upward for South African continent (Figure 6) with South Africa and Swaziland are relatively more globalized. Interestingly, globalization strong advocate, United States has Globalization Index at relatively low between 55 and 65.

Figure 2: Globalization Index: Australia, New Zealand, USA and Canada (1970 - 2013) 


\section{International Journal of Business Management and Economic Review}

Vol. 2, No. 03; 2019

ISSN: 2581-4664



Figure 3: Globalization Index: Selected European countries (1970 - 2013)



Figure 4: Globalization Index: Selected ASEAN countries (1970 - 2013)



Figure 5: Globalization Index: Selected Asian countries (1970 - 2013) 


\section{International Journal of Business Management and Economic Review}

Vol. 2, No. 03; 2019

ISSN: 2581-4664

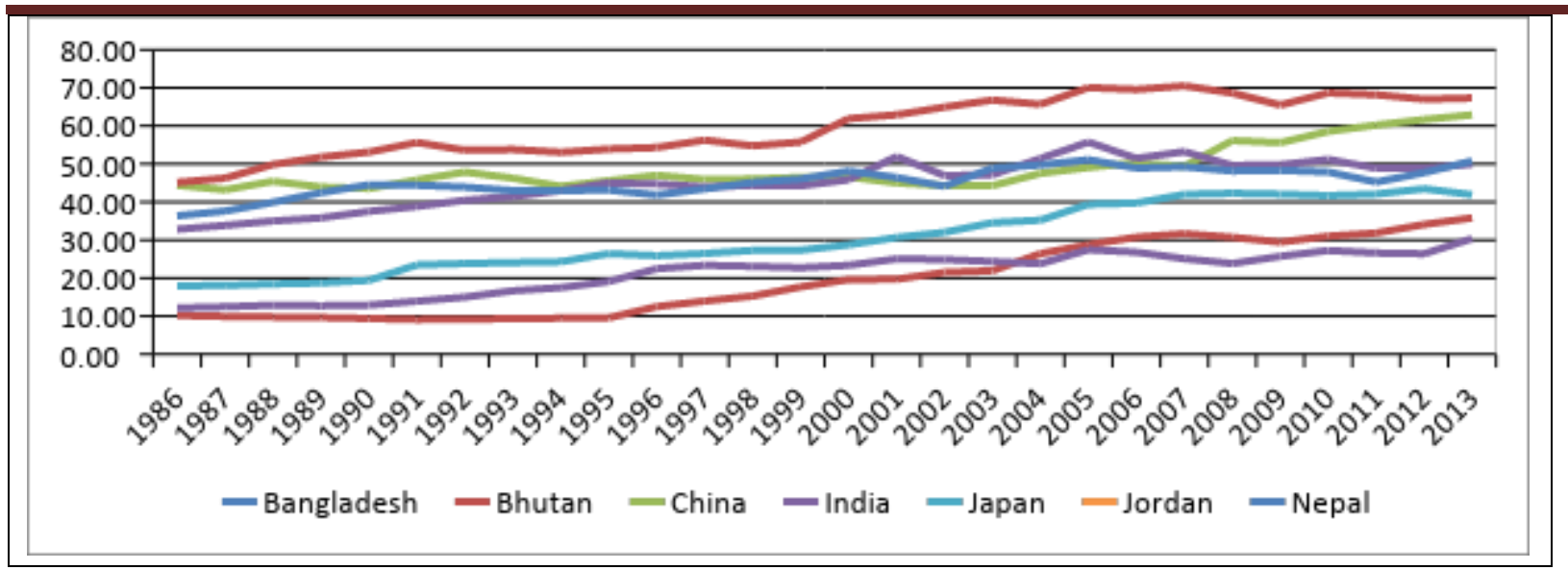

Figure 6: Globalization Index: Selected African countries (1970 - 2013)



Source: All Globalization Index data from ETH Zurich's KOF Swiss Economic Institute (2017)

Are global economies currently divided into three blocks, namely the rapid globalized Asians, the steady South Africans and the reversed globalized developed Western economies? Immigration (more specifically to problem of refugees), aids funds and independent monetary policy have been thorny issues since Greece's economic crisis. A one policy fit all model look more and more not suitable across European Union (EU) members. Like Asian, disparities among EU members are more glaring. How same policy that is good to rich and developed Germany does also suits Turkey and Greece? When Greece had crisis, they do not have the sovereign to print money to bailout their economy. Great Briton citizens look like more frustrated than proud to be second largest net contributor to EU funds. Exit EU saves them lots of money for the development and welfare of their own country. European blue collar workers can work freely in developed EU countries. So do refugees from non-EU countries after they get a visa from any one of EU members.

Reversed globalization in Europe starts from intention for economies disintegration. To some 
extent, sentiment of nationalism and anti-refugees do played some roles in political economy of England, France, Germany, Holland and United States. Sooner or later, economies disintegration especially Brexit and "Protect America" will translate into issue of international trades. Surprisingly, the whole European and United States scenarios are completed the opposite in Asia. ASEAN Economic Community (AEC) aims to emulate European Union on economic integration. Regional Comprehensive Economic Partnership (RCEP) wishes to promote trade among members. Belt and Road Initiatives (BRI) has big ambition to build trade routes (railways and sea) that link the world to China and Asia.

\section{Issue \#2: Positioning of BRI with AEC and TPPA}

The idea of a new "Silk Road economic belt" launched by President Xi during his tour of the Central Asian republics in October 2013, will mainly take shape along railway lines connecting several cities in western China to Europe via Central Asia, Iran, Turkey, the Balkans, and the Caucasus across the 11,000-kilometre long Eurasian continent. The Chinese authorities see this transportation infrastructure as a first step toward the creation of a Eurasian "economic corridor, "allowing for the development of the landlocked Central Asian economies and their future integration with both European and Asian markets (Roland 2015 \& Swaine 2015). Both TPPA and BRI promote trade liberalization. This makes them seem as competitor or worst an economic cold war proxy between United States and China. TTPA (despite being created by President Obama and then called off by United States newly elected President Trump) did not have China while BRI did not get support from United States and its closest alliances, namely Japan and Singapore.

Nonetheless, BRI and TPPA have many differences. First, BRI is more towards "one-to-one" trade deals with China. TPPA need whole group to agree on common trade condition like tariff. Terms and conditions are discussed in detail and highly emphasised in TPPA but not as much in BRI. Look like BRI relies on tradition Chinese business practice of trust, guanxi (relationship) and customized agreement between partner countries. Second, BRI is more focused on infrastructure (especially railway and seaport) build-up to facilitate international trade especially to the upper region of Asia to Europe through land and Malacca Strait sea trade route. In contrast, TPPA focuses on reducing tariff and other trade barriers to increase trade volume. Third, institution affiliated to BRI and TPPA are different. TPPA relies more on United StatedJapan dominated World Trade Organization, World Bank and International Monetary Fund (IMF) but infrastructure projects funding under BRI backed up by Asian Infrastructure Investment Bank (AIIB). There are no exclusive restriction on countries joining both TPPA and BRI. Hence, if the TPPA is to be continued with or without United States, they should not be seen as competitors but different window of trade and economic engagement with different blocks of economies in different part of the world under different approaches.

\section{Compatibility with AEC}

ASEAN members need to enhance and maintain their centrality in East Asian regional economic cooperation in order to attract prosperous foreign direct investment into the countries and 


\section{International Journal of Business Management and Economic Review}

Vol. 2, No. 03; 2019

ISSN: 2581-4664

enhance ASEAN's role globally. In line with this, there will be many challenges will occur including internal divisions and of course a good infrastructure and facilities are desperately needed for uncompetitive members which is more poorer compare to other members. During the 27th ASEAN Summit in Kuala Lumpur held in 2016 has implement ASEAN Economic Community (AEC) Blueprint 2025 to help ASEAN into a more dynamic and constantly evolving in economies as well as domestic and external environments. AEC Blueprint 2025 able to eliminating tariffs and facilitating trade; advancing the services trade liberalisation agenda; liberalising and facilitating investment; streamlining and harmonising capital market regulatory frameworks and platforms; facilitating skilled labour mobility; promoting the development of regional frameworks in competition policy, consumer protection and intellectual property rights; promoting connectivity; narrowing the development gap; and strengthening ASEAN's relationship with its external parties. Thus, one of the major focuses for ASEAN members is the barriers and the building infrastructure connectivity. Concentration may not only on the movement of goods and capital freely but also a synergizing policy coordination and improved mechanisms.

China's Belt and Road Initiative (also known as One Belt, One Road or OBOR) is one of the foreign and economic policies to strengthen China's economic leadership through a vast program of infrastructure building throughout China's neighbouring regions. The regional development aspect of BRI is perhaps one of China's most important economic policy objectives. However, if the Chinese Government fails to connect its domestic projects with overseas components, BRI will be little different from other domestic infrastructure programs, greatly diminishing its economic and strategic value. From this view, ASEAN should participate more in the developing regional or global economic governance, with the aim of integrating with the Chinese economy and other big powers through China's Belt and Road Initiative. With all this interactions, it may foresee to assist ASEAN to become more strong and powerful in economy and a louder voice in global economic forums. China and ASEAN shall become a great partner to cooperate with each other. To realise this, it is very significant for China to resolve all conflicts and contradictions with ASEAN through a policy consultation, coordination and collaboration. The synergy between BRI and the AEC Blueprint 2025 can be at two level forms. One is national level and another in regional level form. At the national level, China wants to use BRI to migrate whole production facilities to deal with the excess capacity production problem. China has the potential to transfer some of its high-quality production capacity to South-east Asian countries, especially Cambodia, Laos, Myanmar and Vietnam (Zhao 2016). Thus, China not only solves the excess capacity problem but also meets the demand for more investment and technology in South-east Asia. In return, China also wants to import more of their manufactured products which also can make BRI more sustainable.

Within the regional level, BRI is also compatible with ASEAN's vision in this connectivity. To promote regional and cross-continental connectivity, some plans like Initiative for ASEAN Integration Work Plan and the Master Plan on ASEAN Connectivity were used to close the development gaps. Another example like Lancang-Mekong Cooperation framework is also used to improve the connectivity for lagging countries. China and ASEAN believe that the Asian 


\section{International Journal of Business Management and Economic Review}

Vol. 2, No. 03; 2019

Infrastructure Investment Bank and Maritime Silk Road Fund under the BRI framework will play a big role in developing ASEAN connectivity. At the current level, BRI-AEC development projects seems to be well developed, however ASEAN members may take full advantage on China's initiative under the BRI. At some point, the connections of the new infrastructure would tie South-East Asian nations individually to China, rather than connecting China with ASEAN as a whole. It might arouse a threat to ASEAN connectivity, which a key principle in the strength of the organisation. This means ASEAN unity might erode and undermine its conceptual principles. This would recommend ASEAN members to have a more collective position and view on how to handle the BRI initiative. China and ASEAN can achieve mutual or "win-win" partnership through BRI-AEC platform. China's funds and expertise in construction of mega infrastructure projects could be beneficial to developing ASEAN. In return, ASEAN economies offer better regional-trade condition to China's products through joint productions in ASEAN countries like Malaysia. This is especially for products like halal goods where vast Middle East markets recognized Malaysia's and Indonesia's halal certification but not China, agricultural-based industry and petroleum based-industry where Malaysia and other ASEAN countries are abundant. Having a strategic policy consultation, coordination and collaboration between China and AEC is very vital to synergize between BRI initiatives and AEC visions even it can bring many difficulties and challenges during the period. It believed can create a new momentum to realising the goals of the AEC Blueprint 2025 and to strategically improving China-ASEAN relations by moving into these directions.

\section{Issue \#3: Advantage of BRI to China}

China, as the initiator of "One Belt, One Road (OBOR)" or now more popularly known as Belt and Road Initiative (BRI) stands out as biggest beneficiary. From economic point of view, China takes advantage of connectivity of physical trade roads (mainly railways) to open trade and business opportunities with various countries. Firstly, connection of railways in BRI in the northern part of Asia to Europe reduces transportation costs (Rolland 2015). Since China mostly sponsoring or funding the construction of railways there, it strengthens business relationship (guanxi) in China favor. Secondly, those northern countries within BRI mapping are rich in natural minerals. For examples, Kazakhstan is world leader in reserves of coal, chromite, lead, zinc and uranium (Asian Development Bank, 2010: 63). Kazakhstan also has high production of bauxite (aluminum), copper, iron and steel. Other central Asia countries are also rich in minerals. Examples are Kyrgyz Republic (gold), Tajikistan (antimony, boron, leadand zinc), Turkmenistan (cement, salt and iodine) and Uzbekistan (gold, uranium, silver, tungsten and sulfur) (Asian Development Bank, 2010: 65 - 68). Thus, if China is connected and has good trading relationship with central Asian countries, China can ensure supply of these major natural resources to themselves and control the supply to the world.

Thirdly, BRI can serve as alternative or "safe trade route" for China should cold war or confrontation broke out between China and United States. The United States currently has high control of sea road in Asia. They have military and navy bases in Philippines and Japan as well as great influences to government of other countries includes Singapore, the main sea port in South East Asia. Therefore, besides functions as "trade route", BRI is also seen as China's 
International Journal of Business Management and Economic Review

Vol. 2, No. 03; 2019

ISSN: 2581-4664

"diplomacy road" to enhance international relationship with various countries (Swaine 2015). Fourthly, BRI is alternative source of growth for China economy. Domestic demand is slowing in China. At the same time, China seems has a rather controversial practice of having everything from material and human resources (to even daily staples, as some news claimed) should come from China for its mega infrastructure construction in various countries. This will create new opportunities and markets for Chinese firms which would have a multiplier impact on production of goods and services domestically in China, creating more jobs and higher incomes for the Chinese populace (Nataraj \& Sekhani, 2015:67 - 68). Rolland (2015) claimed that China had announced a $\$ 3$ billion investment fund for infrastructure connectivity projects under BRI initiative. Thus, BRI railways building projects will create new external demand to replace weak domestic demand in China. Thus, BRI will be expected to be the highlight of China's $13^{\text {th }}$ "Five Year Plan" that will guide China's continuous reformation from 2016 to 2020.

\section{Issue \#4: Is De-globalization and BRI relevant to Malaysian economy?}

Globalization brings both good and bad impacts. Several crises in some developing as well as developed countries are examples. Contagious effect from Asian Financial Crisis 1997/98, subprime crisis stated in United States and Greece's economic problems showed the world the vulnerability of a linked economy. Globalization is like a strategy in a famous ancient warfare of "Red Cliff Battle" of the era of Three Kingdoms. Cao Coa's strategy to chain his ships successfully enhanced stability and reduce seasickness to his troops. Yet, when opponents attacked with fire, all his chained ships were burn easily. Globalization can chained economies together but when crisis (fire) broke off in either one of its member, all other members can be easily effected. Furthermore, chaining the big and small economies together may help the later to grow faster but still far from enough to achieve global economic convergence as envisioned in globalization. Therefore, global institutions like World Trade Organization, International Monetary Fund and World Bank should re-plan, reshape and restructure capital and trade movement even by necessary restrictive measures. This is to enable gain from globalization outweigh cost of open up the economy. The same applies to BRI. It should be structured in a flexible ways to prevent contagious fire but enable trickling down benefit to help smaller economies grow faster and stronger.

Literature reviews show economic globalization brings inconclusive results especially to developing countries, in which BRI can take them as precautious lessons. Cuneyt (2015), Stannia, Alla, and Sri (2015), Dreher (2006) and Ying, Chang, and Lee (2014) supported positive benefit from globalization to growth. Scatter graphs in Figure 7 and Figure 8 plot total trade and annual percentage growth rates of gross domestic product (GDP) respectively against Economic Globalization Index for Malaysia, Singapore, Indonesia, Philippines and Thailand. Graphically, Globalization Index positively related total trade for all countries except Philippines (Figure 7) but did not show any pattern of relationship with growth (Figure 8) for all countries. This may imply that globalization brings in more international trades but does not translate into a meaningful support for sustainable growth.

In fact, Rodrik (1997) has warned that globalization can divide groups of society, thus causing 


\section{International Journal of Business Management and Economic Review}

Vol. 2, No. 03; 2019

ISSN: 2581-4664

social disintegration. Among other negative effects of globalization to development are inequalities (Dreher 2006), inverted U curve relationship for poverty (Agenor 2004) and environmental Kuznets curve on pollution (Shahbaza, Mallickb, Mahalikc, \& Loganathand 2015). Hence, will BRI globalize our economies and open up our trade? How will BRI benefit other countries and therefore Malaysia? China can play three roles to benefit Malaysia, namely (i) filling up Western de-globalization void, (ii) making Malaysia as ASEAN-China Gateway, and (iii) trade enhancement.

Figure 7: Total Trade and Globalization Index (1970 - 2013)

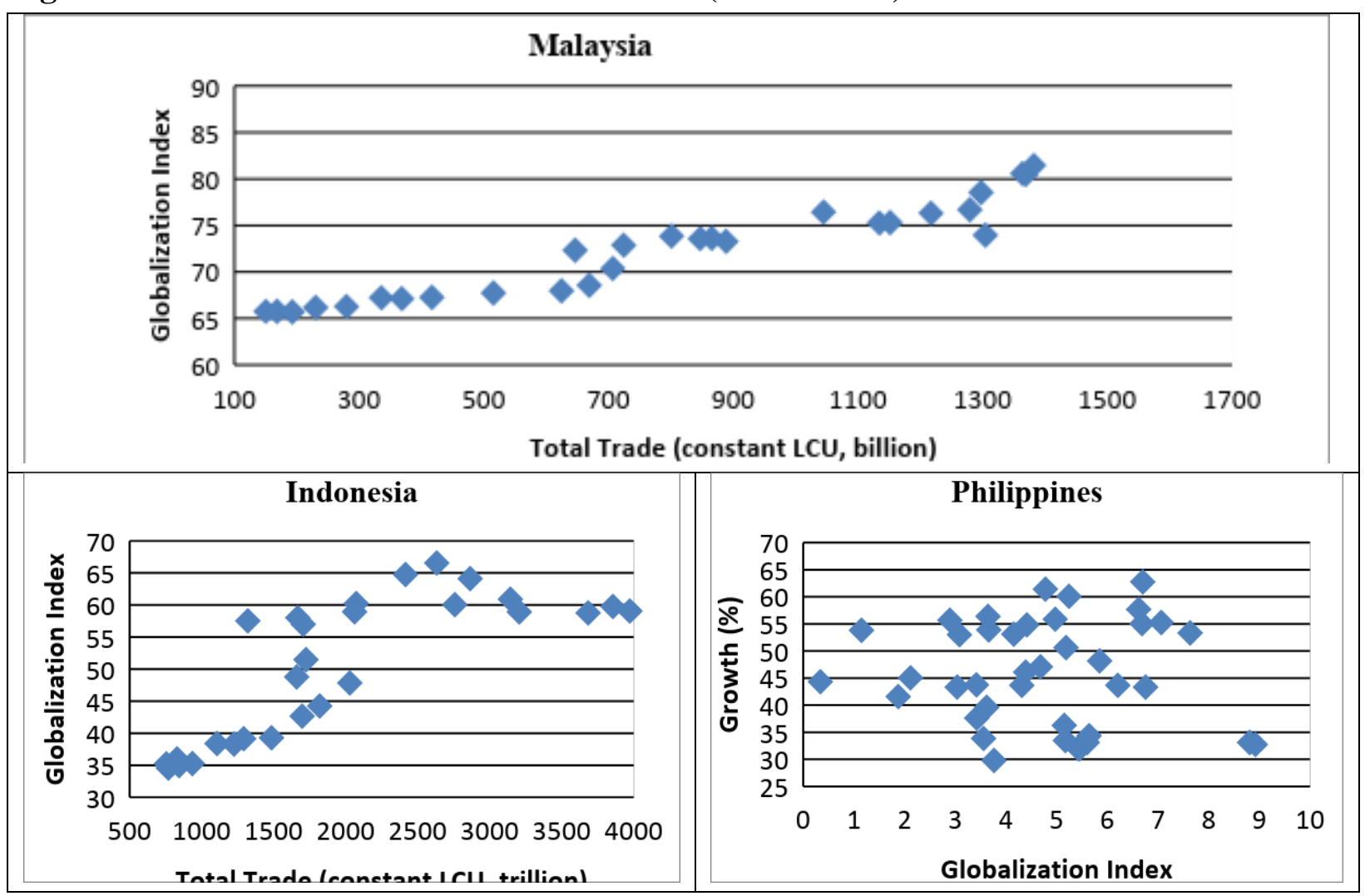


International Journal of Business Management and Economic Review

Vol. 2, No. 03; 2019

ISSN: 2581-4664

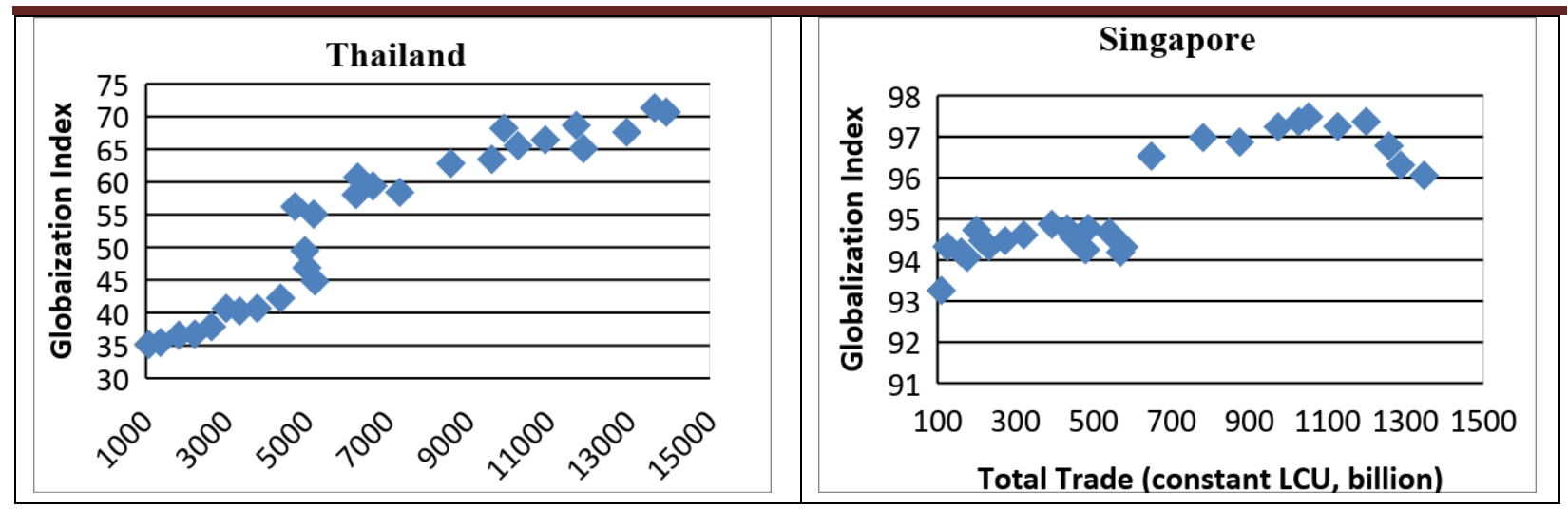

Source: World Bank (for total trade) and ETH Zurich's KOF Swiss Economic Institute (2017). Note: Total trade $=$ export plus import, in real term, local currency unit.

Figure 8: Growth and Globalization Index $(1970$ - 2013)

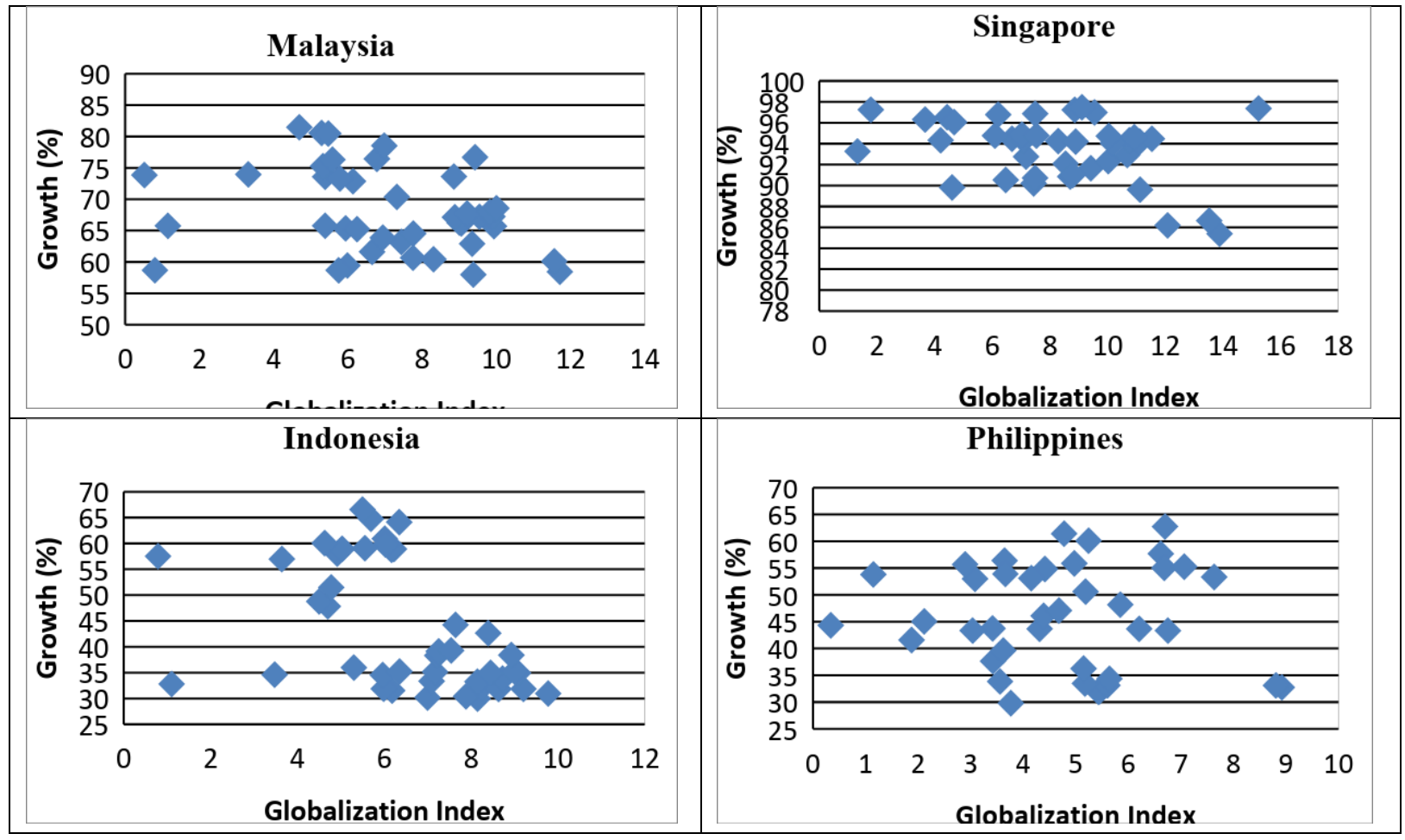


International Journal of Business Management and Economic Review

Vol. 2, No. 03; 2019

ISSN: 2581-4664


Source: World Bank (for growth rates) and ETH Zurich's KOF Swiss Economic Institute (2017). Note: Negative growth rates are excluded to eliminate outliners.

\section{China Filling Up the Void of Western De-globalization}

In economic sphere, China's funds and expertise in construction of mega infrastructure projects could be beneficial to developing ASEAN. Basic economic theory briefly assumes "saving equal investment" and then, investments generate growth. In reality, intermediaries play important roles to turn saving into investments and growth. Besides financial market, infrastructure development is another main intermediary. Three Directors from McKinsey, Garemo, Matzinger, and Palter (2015) echoed important of infrastructure mega project to cities, states and individual livelihoods with few glaring examples. They are Panama Canal, which accounts for a significant share of the country's GDP; Dubai's international airport which is the world's busiest, accounting for 21 percent of Dubai's employment and 27 percent of its GDP; Hong Kong subway and MTR system, which has enabled the densely packed city to build beyond the downtown districts and North Sea Protection Works in Netherlands, which guards the low-lying country's landscape.

Back to Malaysia currently, few mega infrastructure and commercial projects has been at news spotlight, especially the East Coast Rail Link (ECRL), Melaka Gateway Project (MGP), Malaysia-China Kuantan Industrial Park (MCKIP) and Bandar Malaysia. Coincidently, all these projects involve investment or construction from China. In the past decades, these roles would have been taken up by developed Western countries like United States, Germany, United Kingdom and France as well as Japan and South Korea. Few hundred years back after World War II witnessed United States taken the main role as "white-man burden" to "save" the less developed countries all over the world as they afraid of them falling into the hand of communism. As crisis upon crisis hit the developed countries, each of them has their own backyard problems to clean up. Donald Trump starts blaming United States' offshore investments to low labour cost countries as cause to unemployment problem at home. He also sees TPPA and United States' trade as not benefiting themselves. United States is having huge debt and trade deficit. In contrast, China economy is continuously booming for decades long with huge trade surplus thanks to its superior cost competitiveness. These have accumulated lots of funds and foreign reserves to China, which in turn put back into United States through buying 


\section{International Journal of Business Management and Economic Review}

Vol. 2, No. 03; 2019

ISSN: 2581-4664

their government securities. Perhaps, China sees more benefit to invest themselves into Belt and Road Initiative to sustain their long term economic growth and fills the "white-man burden" void left over by those developed countries who seem embarking on reversed globalization (as indicated in the Globalization Index in Figure 3). In addition, the globalization model propagated by the Western developed economies are not flawless either. Asian crisis 1997/98, contagious effect from crisis in developed economies and statistical trend in Figure 8 do not give much support regarding benefit from globalization and trade integration model of the West.

\section{Malaysia as ASEAN-China Gateway}

Rational behaviour theory always assumes no party is willing to do business at a loss. "Whiteman burden" is not a pure charity that came from United States with no condition or expected return attached. Hence, it is for the BRI participating countries to bargain for a mutually beneficial cooperation condition. ASEAN economies offer better regional-trade condition to China's products through joint productions in ASEAN countries like Malaysia. In another words, China direct export to ASEAN countries may subject to higher tax as compare to products made in one of ASEAN countries, subjected to meeting the minimum local content criteria. These advantages are tapped by big corporations like Totoya and Honda in both Thailand and Indonesia. Their investments are welcome because they generate employment, domestic output, revenue and positive spill over effects. Malaysia can be ASEAN gateway for China while new mega infrastructures can transform Malaysia into global assembly hub cum international gateway. This is especially for products like halal goods where vast Middle East markets recognized Malaysia's halal certification but not China, agricultural-based industry and petroleum based-industry where Malaysia and other ASEAN countries are abundant. Export from Western side of Malaysia (especially India and Europe) can go to Port Klang and transport through ECRL to Kuantan Port for export to Eastern side of Malaysia (like Japan, Korea and China) and well as Indonesia and Australasia.

\section{Trade Enhancement}

The Belt and Road Forum for International Cooperation (BRF) was held on $14^{\text {th }}$ to 15 th May 2017 at Beijing. Xinhua News Agency (2017) reported twenty-nine foreign heads of state and government (including Malaysia) attended the forum. Other delegates included officials, entrepreneurs, financiers and media from over 130 countries and regions, which cover more than two thirds of the world's population and $90 \%$ of the world's total GDP. Besides China, only Indonesia, Vietnam and Philippines are among the head of state and government that attend the BRF that are Malaysia's Top 20 destinations for export and import as in Table 1. China is Malaysia second largest (in term of trade value) export destination but largest import destination. The optimistic point of view will see Malaysia getting more trades with countries that support BRI. Among those BRI big export destinations are Russia, Spain, Italy, Turkey, Pakistan, Uzbekistan, Kazakhstan, Kenya, Ethiopia, Argentina and Chile, covering gateways for South Asia, Central Asia, Europe, Africa and Latin America markets. Based on Table 1, Malaysia's trades heavily come from five countries, namely Singapore, China, United States, Japan and Thailand. Those Top 5 trade partners collectively contributed 51\% of total export and 53\% of total import. Top 20 trading partners already consist of $88 \%$ and $89 \%$ of our total export and import respectively. Therefore, BRI give Malaysia not only trade expansion (especially export) 
International Journal of Business Management and Economic Review

Vol. 2, No. 03; 2019

ISSN: 2581-4664

opportunities with existing partners but also trade creation and trade dispersion with other countries. Overly concentrated our trade with only five to twenty countries is not healthy.

Table 1: Top 20 Malaysia's Export and Import Destinations in 2016

\begin{tabular}{|c|c|c|c|c|c|c|c|}
\hline & Partner (Export) & $\begin{array}{l}\text { Trade } \\
\text { Value } \\
\text { (US\$ bil) }\end{array}$ & $(\%)$ & & Partner (Import) & $\begin{array}{l}\text { Trade } \\
\text { Value } \\
\text { (US\$ bil) }\end{array}$ & (\%) \\
\hline 1 & Singapore & 27.58 & 14.56 & 1 & China* & 34.31 & 20.38 \\
\hline 2 & China* & 23.75 & 12.54 & 2 & Singapore & 17.45 & 10.37 \\
\hline 3 & USA & 19.35 & 10.22 & 3 & Japan & 13.73 & 8.16 \\
\hline 4 & Japan & 15.25 & 8.05 & 4 & USA & 13.42 & 7.97 \\
\hline 5 & Thailand & 10.63 & 5.61 & 5 & Thailand & 10.21 & 6.06 \\
\hline 6 & $\begin{array}{ll}\text { China, Hong } & \text { Hong SAR }\end{array}$ & 9.07 & 4.79 & 6 & Other Asia, nes & 10.08 & 5.99 \\
\hline 7 & India & 7.71 & 4.07 & 7 & Rep. of Korea & 8.84 & 5.25 \\
\hline 8 & Indonesia* & 6.67 & 3.52 & 8 & Indonesia* & 7.09 & 4.21 \\
\hline 9 & Australia & 6.45 & 3.40 & 9 & Germany & 5.73 & 3.40 \\
\hline 10 & Viet Nam* & 5.73 & 3.03 & 10 & Viet Nam* & 4.54 & 2.69 \\
\hline 11 & Rep. of Korea & 5.49 & 2.90 & 11 & India & 4.01 & 2.38 \\
\hline 12 & Germany & 5.37 & 2.84 & 12 & Australia & 3.76 & 2.23 \\
\hline 13 & Netherlands & 5.29 & 2.79 & 13 & $\begin{array}{ll}\text { China, } & \text { Hong } \\
\text { Kong SAR } & \end{array}$ & 3.05 & 1.81 \\
\hline 14 & Other Asia, nes & 5.10 & 2.69 & 14 & Saudi Arabia & 2.56 & 1.52 \\
\hline 15 & Philippines* & 3.29 & 1.74 & 15 & $\begin{array}{l}\text { United Arab } \\
\text { Emirates }\end{array}$ & 2.34 & 1.39 \\
\hline 16 & $\begin{array}{l}\text { United Arab } \\
\text { Emirates }\end{array}$ & 3.03 & 1.60 & 16 & France & 2.29 & 1.36 \\
\hline 17 & United Kingdom & 2.11 & 1.11 & 17 & Brazil & 2.04 & 1.21 \\
\hline 18 & Mexico & 1.89 & 1.00 & 18 & Switzerland & 1.72 & 1.02 \\
\hline 19 & Turkey* & 1.73 & 0.91 & 19 & Netherlands & 1.69 & 1.01 \\
\hline 20 & France & 1.42 & 0.75 & 20 & Philippines* & 1.59 & 0.94 \\
\hline \multicolumn{2}{|c|}{ World (Total Export) } & 189.41 & 100.00 & & ld (Total Import) & 168.38 & 100.00 \\
\hline
\end{tabular}

Note: "nes" means "areas not elsewhere specified"; “*” the twenty-nine foreign heads of state and government (plus China) attended the BRF. Data source from UN Comtrade (2017).

In addition, collectively through Kuantan Port, Port Klang and Malacca Gateways deep sea port and ECRL, Malaysia can emulate Singapore as busy entrepot. ECRL projected to carry close to 53 million tonnes of cargo per year by 2040 (Kana \& Kuar 2017: 14 - 15). This figure is criticized by renowned researchers as impossible given KTMB can only carries 6 million tonnes per year in its nationwide network currently. It represents nine fold increases. However, if we take Singapore shipping cargo (as in Table 2) as benchmark, vessel arrival reached 2.66 billion 
gross tonnes in 2016. Cargo throughput is 593.3 million tonnes. The projected 53 million tonnes is merely $2 \%$ of Singapore vessel arrival volume or $8.9 \%$ of Singapore cargo throughput volume. Therefore, the question (or its conclusion) should not be whether ECRL can achieve its targeted tonnages but can Kuantan Port attract international shipment to provide such tonnage for ECRL?

Table 2: Singapore's Maritime Statistics (2012 to 2016)

\begin{tabular}{llllll}
\hline Year & $\begin{array}{l}\text { Vessel } \\
\text { Tonnage } \\
\text { GT) }\end{array}$ & $\begin{array}{l}\text { Arrival } \\
\text { (billion }\end{array}$ & $\begin{array}{l}\text { Container } \\
\text { Throughput } \\
\text { (million TEUs) }\end{array}$ & $\begin{array}{l}\text { Cargo } \\
\text { Throughput } \\
\text { (million tonnes) }\end{array}$ & $\begin{array}{l}\text { Bunker } \\
\text { Volume } \\
\text { (million tonnes) }\end{array}$ \\
\hline 2012 & 2.25 & 31.6 & 538.0 & Sale \\
2013 & 2.33 & 32.6 & 560.9 & 42.7 \\
2014 & 2.37 & 33.9 & 581.3 & 42.7 \\
2015 & 2.50 & 30.9 & 575.8 & 42.4 \\
2016 & 2.66 & 30.9 & 593.3 & 45.2 \\
\hline
\end{tabular}

Source: Maritime and Port Authority of Singapore (2017)

World Shipping Council (2017) highlighted that liner exports are highly concentrated, with the top ten exporting nations accounting for nearly two-thirds of the total liner export value. Greater China (mainland China, Hong Kong and Taiwan) accounted for $28 \%$ of the value of liner exports and $30 \%$ of the global volume of containerized exports. In 2014, China export volume is 36.0 million TEU (Twenty Foot Equivalent Unit). In the same year, South Korea, Japan and Taiwan exports are 5.93 million TEU, 5.28 million TEU and 3.25 million TEU respectively as in Table 3. Each TEU is equivalent to about 2.44 tonnes container weight plus maximum 21.56 tonnes of load. Based on Table 2, shipments to Singapore port have an average 18 tonnes per TEU. Hence, China alone exported $36 \times 18=648$ tonnes of shipment, which is more than tenfold of ECRL target tonnage.

Table 3: Top 20 Exporters of Containerized Cargo: 2010, 2013 \& 2014 (million TEU)

\begin{tabular}{lllll}
\hline & Exporter & 2014 & 2013 & 2010 \\
\hline 1 & China & 36.0 & 34.2 & 31.3 \\
2 & United States & 11.9 & 11.5 & 11.2 \\
3 & South Korea & 5.93 & 5.79 & 5.20 \\
4 & Japan & 5.28 & 5.20 & 5.74 \\
5 & Indonesia & 4.00 & 3.59 & 3.00 \\
6 & Thailand & 3.92 & 3.78 & 3.40 \\
7 & Germany & 3.32 & 3.24 & 3.00 \\
8 & Taiwan, China & 3.25 & 3.24 & 3.41 \\
9 & India & 3.07 & 2.95 & 1.90
\end{tabular}




\section{International Journal of Business Management and Economic Review}

Vol. 2, No. 03; 2019

ISSN: 2581-4664

\begin{tabular}{lllll}
\hline 10 & Vietnam & 2.94 & 2.63 & 1.61 \\
11 & Brazil & 2.88 & 2.74 & 2.30 \\
12 & Malaysia & 2.60 & 2.50 & 2.50 \\
13 & Saudi Arabia & 2.24 & 2.20 & 1.60 \\
14 & Italy & 1.83 & 1.77 & 1.60 \\
15 & Turkey & 1.82 & 1.66 & 1.60 \\
16 & Spain & 1.72 & 1.61 & -- \\
17 & Canada & 1.70 & 1.65 & 1.60 \\
18 & Singapore & 1.57 & 1.48 & 1.60 \\
19 & Netherlands & 1.54 & 1.35 & 1.60 \\
20 & Australia & 1.45 & 1.43 & -- \\
\hline & World Total & 127.60 & 122.35 & \\
\hline
\end{tabular}

Source: World Shipping Council (2017)

\section{CONCLUSION}

Contrasting phenomena took place recently. Building infrastructures to promote international trade under Belt and Road Initiative (BRI) are China's way of rejuvenation towards prosperous, strong, culturally advanced and harmonious country. In contrast, Donald Trump's chooses protectionism to "Make America Great Again". ASEAN countries going towards ASEAN Economic Community (AEC) but Britain choose to exit European Union. These contrasting phenomena prompt four research questions. Firstly, is there a reversed globalization wave? Secondly, how can BRI position itself with Trans-Pacific Partnership Agreement (TPPA) and AEC? Third and fourth, what benefits can BRI bring to China and Malaysia respectively? Analysis of Globalization Indexes from ETH Zurich's KOF Swiss Economic Institute reveals reversed economic globalization trend after 2000 for United States, Canada, Australia and major European countries. Asian countries are globalizing rapidly since 1986 while South African countries see stable globalization trend. Therefore, BRI plays important role to lead ASEAN's globalization. In economic sphere, China's funds and expertise in construction of mega infrastructure projects could be beneficial to developing ASEAN. In return, ASEAN economies offer better regional-trade condition to China's products through joint productions in ASEAN countries like Malaysia. This is especially for products like halal goods where vast Middle East markets recognized Malaysia's halal certification but not China, agricultural-based industry and petroleum based-industry where Malaysia and other ASEAN countries are abundant. BRI also play important role in trade enhancement among China and participating countries.

\section{REFERENCE}

Agenor, P.R. (2004). Does globalization hurt the poor?. International Economics and Economic Policy. Vol.1(1): $21-51$.

Asian Development Bank (2010). Central Asia Atlas of Natural Resources. Manila: Asian Development Bank. 
Cuneyt, K. (2015). Effect of globalization on economic growth: Panel data analysis for developing countries. Economic Insights - Trends and Challenges. Vol. 4: 1 - 11.

Dreher, Axel (2006): Does Globalization Affect Growth? Evidence from a new Index of Globalization. Applied Economics. Vol. 38(10): 1091-1110.

Garemo, N, Matzinger, S. and Palter, R. (2015). Megaprojects: The good, the bad, and the better. Available at http://www.mckinsey.com/industries/capital-projects-and-infrastructure/ourinsights/megaprojects-the-good-the-bad-and-the-better. Access date: 20th August 2018.

Kana, G. and Kuar, G. (2017). The real economics of ECRL. The Star newspaper, Biz Week section: $14-15,12$ th August.

KOF Swiss Economic Institute. (2017). Globalization Indexes, variety years.

Maritime and Port Authority of Singapore. (2017). Singapore's 2016 Maritime Performance. Retrieved on 20 August 2017 from http://www.mpa.gov.sg/web/portal/home/mediacentre/news-releases/detail/05460688-fe49-42e7-9740-4ce88b157b46. 11 January.

Nataraj, G and Sekhani,R. (2015). China's One Belt, One Road: An Indian Perspective. Economic and Political Weekly. Vol. 50 (49): $67-71$.

New York Times. (2016). Brexit, Explained: 7 Questions About What It Means and Why It $\begin{array}{llllll}\text { Matters. } & \text { Retrieved } & \text { on } & 20 & \text { March } & 2017\end{array}$ from https://www.nytimes.com/2016/06/21/world/europe/brexit-britain-eu-explained.html.

Rodrik, D. (1997). Has globalization gone too far?. California Management Review. Vol. 39(3): $29-53$.

Rolland, N. (2015). China's New Silk Road. The National Bureau of Asian Research. Feb 12.

Shahbaza, M., Mallickb, H., Mahalikc, M.K. and Loganathand, N. (2015). Does globalization impede environmental quality in India? Ecological Indicators. Vol. 52: 379 -393.

Stannia, C. S., Alla, A., and Sri, M. (2015). The impact of globalization on economic growth in ASEAN. International Journal of Administrative Science and Organization. Vol. 22: 79- 87.

Swaine, M.D. (2015). Chinese views and commentary on the "One Belt, One Road" initiative. China Leadership Monitor. Vol.47.

UN Comtrade. (2017), various data.

World Shipping Council. (2017). Trade statistics. Retrieved on 23 August 2017 from http://www.worldshipping.org/about-the-industry/global-trade/trade-statistics.

Xinhua News Agency. (2017). Belt and Road forum points clear way for future cooperation: Chinese State Councilor. Retrieved on 22 August 2017 from http://news.xinhuanet.com/english/2017-05/17/c_136292793.htm. 17th May.

Ying, Y. H., Chang, K., and Lee, C. H. (2014). The impact of globalization on economic growth. Romanian Journal of Economic Forecasting. Vol. 17: 25 - 34.

Zhao, H. (2016). Can China's OBOR Initiative Synergize with AEC Blueprint 2025? ISEAS Perspective. Issue no. 62. 